\title{
Chemical Composition and Biological Activities of Metabolites from the Marine Fungi Penicillium sp. Isolated from Sediments of Co To Island, Vietnam
}

\author{
Hong Minh Thi Le ${ }^{1, *}$, Quynh Thi Do ${ }^{1,2}$, Mai Huong Thi Doan ${ }^{1}$, Quyen Thi Vu ${ }^{1}$, \\ Mai Anh Nguyen ${ }^{1}$, Thu Huyen Thi Vu ${ }^{1}$, Hai Dang Nguyen ${ }^{3}$, Nguyen Thi Thuy Duong ${ }^{4}$, \\ Manh Hung Tran ${ }^{4, * \mathbb{D}}$, Van Minh Chau ${ }^{1}$ and Van Cuong Pham ${ }^{1}$ \\ 1 Institute of Marine Biochemistry, Vietnam Academy of Science and Technology, 18 Hoang Quoc Viet, \\ CauGiay, Hanoi 100803, Vietnam; quynhdt1992@gmail.com (Q.T.D.); huongdm@imbc.vast.vn (M.H.T.D.); \\ svuquyen@yahoo.com (Q.T.V.); maianhhsb@gmail.com (M.A.N.); huyenvuibt@gmail.com (T.H.T.V.); \\ minhcv@vast.vn (V.M.C.); phamvc@imbc.vast.vn (V.C.P.) \\ 2 Graduate University of Science and Technology, Vietnam Academy of Science and Technology, \\ 18 Hoang Quoc Viet, CauGiay, Hanoi 100803, Vietnam \\ 3 University of Science and Technology of Hanoi (U.S.T.H.), Vietnam Academy of Science and Technology, \\ 18 Hoang Quoc Viet, CauGiay, Hanoi 100803, Vietnam; nguyenhd@imbc.vast.vn \\ 4 Biomedical Science Department, Institute for Research \& Executive Education (V.N.U.K.), The University of \\ Danang, 158A Le Loi, Hai Chau District, Danang City 551000, Vietnam; duong.nguyen@vnuk.edu.vn \\ * Correspondence: lhminhbk@gmail.com (H.M.T.L.); tmhung801018@gmail.com (M.H.T.)
}

Academic Editor: Derek J. McPhee

Received: 26 September 2019; Accepted: 23 October 2019; Published: 24 October 2019

\begin{abstract}
Marine microorganisms are an invaluable source of novel active secondary metabolites possessing various biological activities. In this study, the extraction and isolation of the marine sediment Penicillium species collected in Vietnam yielded ten secondary metabolites, including sporogen AO-1 (1), 3-indolecarbaldehyde (2), 2-[(5-methyl-1,4-dioxan-2-yl)methoxy]ethanol (3), 2-[(2R-hydroxypropanoyl)amino]benzamide (4), 4-hydroxybenzandehyde (5), chrysogine (6), 3-acetyl-4-hydroxycinnoline (7), acid 1H-indole-3-acetic (8), cyclo (Tyr-Trp) (9), and 2',3'-dihydrosorbicillin (10). Their structures were identified by the analysis of 1D and 2D NMR data. Among the isolated compounds, 2-[(5-methyl-1,4-dioxan-2-yl)methoxy]ethanol (3) showed a strong inhibitory effect against Enterococcus faecalis with a minimum inhibitory concentration value of $32 \mu \mathrm{g} / \mathrm{mL}$. Both 2-[(2R-hydroxypropanoyl)amino]benzamide (4) and 4-hydroxybenzandehyde (5) selectively inhibited E. coli with minimum inhibitory concentration values of 16 and $8 \mu \mathrm{g} / \mathrm{mL}$, respectively. $2^{\prime}, 3^{\prime}$-Dihydrosorbicillin (10) potentially inhibited $\alpha$-glucosidase activity at a concentration of $2.0 \mathrm{mM}$ $(66.31 \%)$.
\end{abstract}

Keywords: marine fungi Penicillium sp.; 3-acetyl-4-hydroxycinnoline; 4-hydroxybenzandehit; antimicrobiology; $\alpha$-glucosidase

\section{Introduction}

Drug-resistant bacteria have been an emerging global problem in the last few decades and are one of the most serious issues affecting public health. In the treatment of infections, there is a sharp increase in the number of pathogens with multiple drug-resistant agents [1]. Among them, biofilm-synthetic small molecules are microbes that survive in hostile environments and raise the resistance by a thousand-fold. Biofilms potential to cause disease often occurs in Gram-negative pathogens such as Streptococcus pneumoniae, Staphylococcus aureus, and Enterococcus faecium, as well as Gram-negative pathogens such as Escherichia coli and Pseudomonas aeruginosa [2]. Of particular note is some bacteria are 
naturally resistant to a certain antibiotic, but otherwise, antibiotic resistance is the result of the long-term use of antibiotics to treat infections [3]. Recent research revealed that antimicrobial chemotherapy could prevent the pathogenesis of bacterial infection, and simultaneously may induce drug-resistant mutations in bacteria. As stated above, these contrasting outcomes required the urgent exploitation of specific interactions of drugs and modulation of these interactions, which can raise the susceptibility of the bacteria to therapeutic compounds [3].

Recently, marine microorganisms are important sources of novel active secondary metabolites possessing various biological activities, including antibiotics, anti-cancer, and anti-virus [4-6]. In the past few years, a number of biologically active compounds have been isolated from marine microorganisms, which exhibited promising pharmacological applications. Numerous marine natural products are now being tested in the clinical stages [7,8]. The recent progress of advanced technologies in genetic manufacturing and biological activity guided fractionation brought several opportunities to the discovery of marine natural products as lead compounds in the drug development $[9,10]$.

Natural fungi are clarified as one of the huge prolific producers of secondary metabolites. The Penicillium genus, which comprises more than 200 species, is famous since 1920 s due to the discovery of its antibiotic metabolite penicillin. This genus was discovered in some uncommon environments, including permafrost soil [11], wastewater from mines [12], and deep ocean sediments [13]. Penicillium species have been found to generate several bioactive compounds that could be used as antibacterial [14,15], anti-fungal [16], immunosuppressants, cholesterol-lowering agents [17], and even mycotoxins [18]. Since the discovery of penicillin, numerous Penicillium isolates had been examined, and new metabolites from these fungi draw a great range of attentions for scientists. These metabolites showed varied chemical structures such as polyketides [19], tetrameric acids [20], phenols and alkaloids [21] that could be potential sources for the treatment of diseases. Although the metabolites from fungi show promising biological benefits, only a limited number of the marine microbes have been investigated as bioactive agents.

Here, we focused on the extract of fermentation broth of the Penicillium strain M30, which was isolated from the sediment that was collected at a depth of $14 \mathrm{~m}$ sea at the Co To island, Northern Vietnam. This extract showed significantly antimicrobial, $\alpha$-glucosidase, and $\alpha$-amylase inhibitory activities. This study reports the isolation and chemical identification of secondary metabolites from the fermentation broth of the Penicillium strain M30 as well as their biological activity.

\section{Results and Discussion}

\subsection{Identification of Fungus}

The fungus M30 was purified successfully as described in the Materials and Methods (Figure 1). M30 strain's colonies produce white and dry conidiophores.

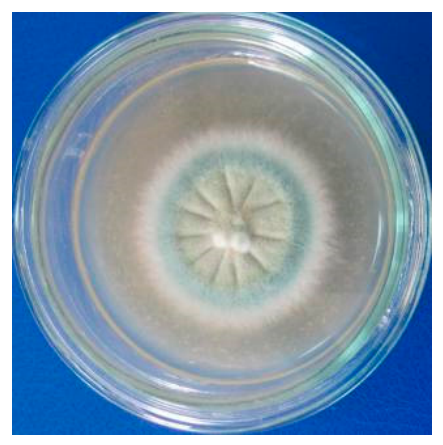

Figure 1. Appearance of M30 strain's colonies.

It is obvious that rRNA is crucial for cell living systems. The rRNA encoding genes are extremely maintained not only in the fungal but also in other kingdoms. Moreover, proteins comprising the ribosomes and rRNA sequences are highly conserved throughout evolution. rRNA analysis is a 
common method used to investigate microbial diversity and to identify new strains. In this study, the M30 strain, as a member of the Penicillium sp., was characterized using genotyping techniques involving the amplification of the subunit of the $18 \mathrm{~S}$ rRNA gene. A total of $1173 \mathrm{bp}$ of the $18 \mathrm{~S}$ rRNA gene was sequenced and used for the identification of the isolated fungal strain. Results showed that the gene sequence of M30 strain has 99\% sequence matching (Score $=2139$ bits, Expect $=0.0$ ) with 18S rRNA gene sequence of Penicillium (GenBank Acc. No.: MH 673731), and thus, this strain belonged to the genus Penicillium.

\subsection{Biological Activities of the Extract of Penicillium sp.}

In the primary experiment, M30 extract was examined for its antibacterial activity against Escherichia coli (ATCC 25922), Pseudomonas aeruginosa (ATCC 27853), Salmonella enterica (ATCC 12228), Enterococcus faecalis (ATCC 13124), Staphylococcus aureus (ATCC 25923), Bacillus cereus (ATCC 13245), and anti-yeast against Candida albicans (ATCC 1023). The results in Table 1 showed that M30 extract inhibited C. albicans with an MIC value of $64 \mu \mathrm{g} / \mathrm{mL}$. This extract also exhibited moderate inhibitory activity against some Gram (+) bacteria including S. aureus (minimum inhibitory concentration - MIC $=256 \mu \mathrm{g} / \mathrm{mL})$, B. cereus $(\mathrm{MIC}=256 \mu \mathrm{g} / \mathrm{mL})$ and the Gram $(-)$ bacterium P. aeruginosa $(\mathrm{MIC}=128 \mu \mathrm{g} / \mathrm{mL})$. Screening results of the $\alpha$-amylase and $\alpha$-glucosidase inhibitory activity revealed that M30 extract exhibited a positive effect against $\alpha$-glucosidase with an $\mathrm{IC}_{50}$ value of $628 \mu \mathrm{g} / \mathrm{mL}$. In this experiment, acarbose, a positive control, showed an inhibitory effect with an $\mathrm{IC}_{50}$ value of $423 \mu \mathrm{g} / \mathrm{mL}$. Considering the potential of the M30 strain, our subsequent study focused on the fermentation of this Penicillium sp. in order to analyze active secondary metabolites contributing to these above biological activities.

Table 1. Minimum inhibitory concentration values of extract and isolated metabolites from Penicillium sp.

\begin{tabular}{|c|c|c|c|c|c|c|c|}
\hline \multirow[b]{2}{*}{ Samples/Compounds } & \multicolumn{3}{|c|}{$\operatorname{Gram}(+)^{(a)}$} & \multicolumn{3}{|c|}{ Gram (-) (a) } & \multirow{2}{*}{$\begin{array}{c}\text { Yeast } \\
\text { (a) }\end{array}$} \\
\hline & 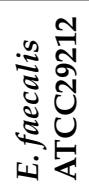 & 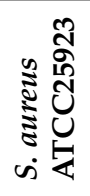 & 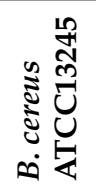 & 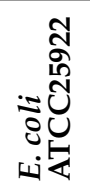 & 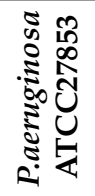 & 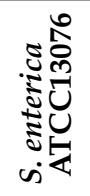 & \\
\hline M30 extract & - & 256 & 256 & - & 128 & - & 64 \\
\hline 1 & 256 & $>256$ & $>256$ & $>256$ & $>256$ & $>256$ & 128 \\
\hline 2 & 256 & $>256$ & $>256$ & $>256$ & $>256$ & $>256$ & 128 \\
\hline 3 & 32 & $>256$ & $>256$ & $>256$ & $>256$ & $>256$ & 64 \\
\hline 4 & $>256$ & $>256$ & $>256$ & 16 & 128 & $>256$ & $>256$ \\
\hline 5 & $>256$ & $>256$ & $>256$ & 8 & $>256$ & $>256$ & $>256$ \\
\hline 6 & $>256$ & $>256$ & $>256$ & 64 & $>256$ & $>256$ & $>256$ \\
\hline 7 & 64 & 256 & 256 & $>256$ & $>256$ & $>256$ & 128 \\
\hline 8 & 64 & 128 & 256 & $>256$ & 128 & 256 & 128 \\
\hline 9 & 256 & $>256$ & $>256$ & $>256$ & $>256$ & $>256$ & $>256$ \\
\hline 10 & $>256$ & $>256$ & $>256$ & $>256$ & $>256$ & $>256$ & $>256$ \\
\hline Streptomycin ${ }^{(b)}$ & 256 & 256 & 128 & 32 & 256 & 128 & - \\
\hline Cyclohexamide $^{(b)}$ & - & - & - & - & - & - & 32 \\
\hline
\end{tabular}

(a) Results are calculated in $\mu \mathrm{g} / \mathrm{mL}$. ${ }^{\text {(b) }}$ Positive compounds.

\subsection{Identification of Compounds}

The ethyl acetate-soluble fraction from M30 was applied to several chromatography techniques such as silica gel, reverse phase-18, and semi-preparative HPLC, resulting in the isolation of ten secondary metabolites (1-10) (Figure 2). The known compounds, sporogen AO-1 (1) [22], 3-indolecarbadehyde (2) [22], 2-[(5-methyl-1,4-dioxan-2-yl)methoxy]ethanol (3) [23], 2-[(2R-hydroxypropanoyl)amino]benzamide (4) [23], 4-hydroxybenzandehyde (5) [24], chrysogine 
(6) [24], acid 1H-indole-3-acetic (8) [25], and cyclo (Tyr-Trp) (9) [26], and 2',3'-dihydrosorbicillin (10) [26] (Figure 2), were elucidated by the examination of their NMR spectra and comparison with literature data.<smiles>C=C(C)[C@H]1C(=O)C=C2CCC(O)C(C)[C@@]2(C)[C@@H]1O</smiles>

1<smiles>O=Cc1c[nH]c2ccccc12</smiles>

2<smiles>C[C@H]1CO[C@@H](COCCO)CO1</smiles>

3<smiles>C[C@H](O)C(=O)Nc1ccccc1C(N)=O</smiles>

4<smiles>O=Cc1ccc(O)cc1</smiles>

5<smiles>CC(O)c1nc2ccccc2c(=O)[nH]1</smiles>

6<smiles>CCC(=O)c1nnc2ccccc2c1O</smiles>

7<smiles>O=C(O)Cc1c[nH]c2ccccc12</smiles>

8<smiles>O=C1N[C@H](Cc2c[nH]c3ccccc23)C(=O)N[C@@H]1Cc1ccc(O)cc1</smiles>

9<smiles>C/C=C/CCC(=O)c1cc(C)c(O)c(C)c1O</smiles>

10

Figure 2. Chemical structures of compounds 1-10.

Compound 7 was isolated as a yellow powder. Its IR spectrum showed typical signals of hydroxyl and ketone groups at $v_{\max } 3412$ and $1669 \mathrm{~cm}^{-1}$, respectively. The high resolution electrospray ionization mass spectrometry (HR-ESI-MS) of 7 presented the pseudomolecular peak at m/z $189.0657[\mathrm{M}+\mathrm{H}]^{+}$ (calculated for $\mathrm{C}_{10} \mathrm{H}_{9} \mathrm{~N}_{2} \mathrm{O}_{2} \mathrm{~m} / \mathrm{z}$ 189.0664), that could be assigned to the molecular formula of 7 is $\mathrm{C}_{10} \mathrm{H}_{8} \mathrm{~N}_{2} \mathrm{O}_{2}$. In the ${ }^{1} \mathrm{H}-\mathrm{NMR}$ spectrum, four methine signals of a 1,2-disubstituted aromatic ring at $\delta_{\mathrm{H}}$ $8.36(\mathrm{~d}, J=8.0 \mathrm{~Hz}, \mathrm{H}-5), 7.63(\mathrm{t}, J=8.0 \mathrm{~Hz}, \mathrm{H}-6), 7.85(\mathrm{t}, J=8,0 \mathrm{~Hz}, \mathrm{H}-7)$, and 7,89 (d, $J=8,0 \mathrm{~Hz}, \mathrm{H}-8)$, one methyl group at $\delta_{\mathrm{H}} 2.77\left(\mathrm{~s}, \mathrm{CH}_{3}-9\right)$, and an $\mathrm{OH}$ signal at $\delta_{\mathrm{H}} 9.95(\mathrm{brs}, \mathrm{OH})$ were observed. The ${ }^{13} \mathrm{C}-\mathrm{NMR}$ and distortionless enhancement by polarization transfer (DEPT) spectrum showed that this metabolite has 10 carbon signals. Among them, a methyl signal at $\delta_{\mathrm{C}} 24.0\left(\mathrm{CH}_{3}-10\right)$, a ketone carbon at $\delta_{\mathrm{C}} 194.1$ (C-9), four methine carbon of aromatic ring, and four quaternary carbons at $\delta_{C} 145.3$ (C-3), 160.6 (C-4), 123.5 (C-4a), and 147.7 (C-8a) were identified. In the heteronuclear multiple bond correlation (HMBC) spectrum, the long-range correlation signals between $\mathrm{H}-5$ and $\mathrm{C}-8 \mathrm{a}$ and $\mathrm{C}-4, \mathrm{H}-8$, and C-4a were identified (Figure 3). Interestingly, the acetyl group was attached to the C-3 that was confirmed by the connection signals between $\mathrm{CH}_{3}-10$ and C-9 and C-3. A combination of the MS, 1D-NMR, and 2D-NMR spectrum of 7 and the comparison with the NMR data of previous literature allowed us to identify 7 as 3-acetyl-4-hydroxycinnoline. This cinnoline derivative was firstly synthesized in 1991 [27]; however, this is the first time the compound was isolated from the Penicillium sp.

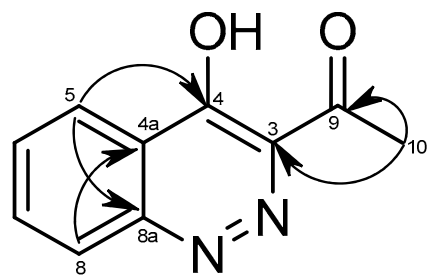

Figure 3. Selected key correlations in the HMBC spectrum ( $)$ of 7.

\subsection{Biological Activities of the Metabolites from Penicillium $s p$.}

All of the isolated secondary metabolites (1-10) were tested for their antibacterial activity toward Escherichia coli (ATCC 25922), Pseudomonas aeruginosa (ATCC 27853), Salmonella enterica (ATCC 12228), Enterococcus faecalis (ATCC 13124), Staphylococcus aureus (ATCC 25923), Bacillus 
cereus (ATCC 13245), and anti-yeast activity against Candida albicans (ATCC 1023). As shown in Table 1, 2-[(5-methyl-1,4-dioxan-2-yl)methoxy]ethanol (3) showed strong inhibitory effect against E. faecalis and C. albicans with MIC values of 32 and $64 \mu \mathrm{g} / \mathrm{mL}$, respectively. In addition, 2-[(2R-hydroxypropanoyl)amino]benzamide (4) and 4-hydroxybenzandehide (5) selectively suppressed E. coli with the MIC value of $16 \mu \mathrm{g} / \mathrm{mL}$ and $8 \mu \mathrm{g} / \mathrm{mL}$, respectively. These compounds showed stronger inhibitory effects than the reference compound, streptomycin, that presented an MIC value of $32 \mu \mathrm{g} / \mathrm{mL}$ (Table 1). Previous studies revealed a strong antimicrobial property for 2-aminobenzamide derivatives and benzaldehyde derivatives [28-30], which have been considered as potential agents for antimicrobial drug discovery. Notably, both of 3-acetyl-4-hydroxycinnoline (7) and 1H-indole-3-acetic (8) exhibited moderate antibacterial ability against $E$. faecalis with MIC value of $64 \mu \mathrm{g} / \mathrm{mL}$.

Among the tested compounds, $2^{\prime}, 3^{\prime}$-dihydrosorbicillin (10) potentially inhibited $\alpha$-glucosidase activity at a concentration of $2.0 \mathrm{mM}(66.31 \%)$ (Table 2). Interestingly, no $\alpha$-amylase inhibitory activity was found in all the tested samples. The present study is the first study on inhibition of $2^{\prime}, 3^{\prime}$-dihydrosorbicillin (10) against $\alpha$-glucosidase. This result suggested that $2^{\prime}, 3^{\prime}$-dihydrosorbicillin (10) may have potential use in the treatment of type 2 diabetes through $\alpha$-glucosidase inhibition.

Table 2. $\alpha$-Glucosidase inhibitory activity of compounds $\mathbf{1 - 1 0 .}$

\begin{tabular}{|c|c|c|}
\hline Sample & Concentration (mM) & $\%$ Inhibition $^{(\mathrm{a})}$ \\
\hline \multirow[b]{2}{*}{ M30 } & $100 \mu \mathrm{g} / \mathrm{mL}$ & - \\
\hline & $500 \mu \mathrm{g} / \mathrm{mL}$ & $44.78 \pm 1.73$ \\
\hline \multirow{2}{*}{1} & 0.5 & - \\
\hline & 2.0 & - \\
\hline \multirow{2}{*}{2} & 0.5 & - \\
\hline & 2.0 & - \\
\hline \multirow{2}{*}{3} & 0.5 & - \\
\hline & 2.0 & - \\
\hline \multirow[b]{2}{*}{4} & 0.5 & $12.19 \pm 2.93$ \\
\hline & 2.0 & $18.44 \pm 3.94$ \\
\hline \multirow{2}{*}{5} & 0.5 & $14.45 \pm 1.28$ \\
\hline & 2.0 & $18.80 \pm 0.54$ \\
\hline \multirow{2}{*}{6} & 0.5 & - \\
\hline & 2.0 & - \\
\hline \multirow{2}{*}{7} & 0.5 & $9.42 \pm 1.03$ \\
\hline & 2.0 & $18.81 \pm 1.97$ \\
\hline \multirow{2}{*}{8} & 0.5 & $19.79 \pm 0.83$ \\
\hline & 2.0 & $40.31 \pm 0.50$ \\
\hline \multirow[b]{2}{*}{9} & 0.5 & $17.91 \pm 1.13$ \\
\hline & 2.0 & $39.23 \pm 0.68$ \\
\hline \multirow{2}{*}{10} & 0.5 & $12.11 \pm 0.60$ \\
\hline & 2.0 & $66.31 \pm 0.09$ \\
\hline \multirow{2}{*}{ Acarbose $^{(b)}$} & $100 \mu \mathrm{g} / \mathrm{mL}$ & $19.69 \pm 2.28$ \\
\hline & $500 \mu \mathrm{g} / \mathrm{mL}$ & $55.18 \pm 0.67$ \\
\hline
\end{tabular}

\section{Materials and Methods}

\subsection{General Experiment Procedures}

The ESI-MS was measured on Agilent 6120 series single quadrupole LC/MS systems (Agilent 6120, Santa Clara, CA, USA). NMR spectra were recorded on a Bruker AM500 FT-NMR spectrometer using transcranial magnetic stimulation (TMS) as an internal standard. Column chromatography (CC) was performed using a silica gel (Kiesel gel 60, 70-230 mesh and 230-400 mesh, Merck, Darmstadt, Germany). Thin layer chromatography (TLC) used pre-coated silica gel 60 F254 (Merck, Germany). 


\subsection{Fungus Isolation}

The marine sediment samples were collected at $14 \mathrm{~m}$ depth with geographic coordinates $2105^{\prime} 11^{\prime \prime}-107050^{\prime} 57^{\prime \prime}$, water at temperature $26^{\circ} \mathrm{C}$ in the Co To Island, Vietnam. The samples were collected into $15 \mathrm{~mL}$ or $50 \mathrm{~mL}$ sterile Falcon tubes and preserved in an ice-box and processed within $24 \mathrm{~h}$. Briefly, $0.5 \mathrm{~g}$ of the sample was suspended in $4.5 \mathrm{~mL}$ of sterile distilled water, homogenized by vortexing for $1 \mathrm{~min}$, and the suspension was treated using a wet-heat technique ( $60{ }^{\circ} \mathrm{C}$ for $\left.6 \mathrm{~min}\right)$. Next, $0.5 \mathrm{~mL}$ of this suspension was transferred to $4.5 \mathrm{~mL}$ sterile distilled water, and this step was repeated to set up a ten-fold dilution series to $10^{-3}$. At the final dilution step, aliquots of $50 \mu \mathrm{L}$ were spread on medium A1 (soluble starch: $10 \mathrm{~g} / \mathrm{L}$; yeast extract: $4 \mathrm{~g} / \mathrm{L}$; peptone: $2 \mathrm{~g} / \mathrm{L}$; instant ocean: $30 \mathrm{~g} / \mathrm{L}$; agar: $15 \mathrm{~g} / \mathrm{L}$ ) supplemented with $50 \mu \mathrm{g} / \mathrm{mL}$ polymycin B to inhibit Gram-negative bacteria. The plates were incubated at $28{ }^{\circ} \mathrm{C}$ for seven days. The colony of fungus M30 was transferred onto a new Petri dish of medium A1 for purification.

\subsection{Fungus Identification}

Genomic DNA was extracted with the Gen Elute Bacterial Genomic DNA kit (Sigma, St. Luis, MO, USA). Sequences of $18 \mathrm{~S}$ rRNA was used for identification of the strain. The gene amplifications were performed in a $25.0 \mu \mathrm{L}$ mixture containing $16.3 \mu \mathrm{L}$ of distilled water, $2.5 \mu \mathrm{L}$ of $10 \mathrm{X}$ polemerase chain reaction (PCR) buffer, $1.5 \mu \mathrm{L}$ of $25 \mathrm{mM} \mathrm{MgCl}_{2}, 0.5 \mu \mathrm{L}$ of $10 \mathrm{mM}$ deoxynucleotide (dNTP's), $0.2 \mu \mathrm{L}$ of Taq polymerase, $1.0 \mu \mathrm{L}$ for both $0.05 \mathrm{mM}$ of NS3F (5'-GCAAGTCTGGTGCCAGCAGCC 3') and $0.05 \mathrm{mM}$ of NS8R (5'-TCCGCAGGTTCACCTACGGA 3') primers and $2.0 \mu \mathrm{L}$ of genomic DNA. The reaction tube was then put into an MJ Thermal cycler, which had been programmed to preheat at $94{ }^{\circ} \mathrm{C}$ for $3 \mathrm{~min}$, followed by 30 cycles of denaturation at $94{ }^{\circ} \mathrm{C}$ for $1 \mathrm{~min}$, annealing at $62^{\circ} \mathrm{C}$ for $30 \mathrm{~s}$, and elongation at $72{ }^{\circ} \mathrm{C}$ for $45 \mathrm{~s}$ before a final extension of $72{ }^{\circ} \mathrm{C}$ for $10 \mathrm{~min}$. The estimated PCR product size was about $1300 \mathrm{bp}$. PCR products were purified by the DNA purification kit (Invitrogen) then sequenced by a DNA Analyzer (ABI PRISM 3100, Applied Bioscience, Carlsbad, CA, USA). Gene sequences were handled by BioEdit v.2.7.5 and compared with bacterial 18S rRNA sequences in the GeneBank database by the National Center for Biotechnology Information (NCBI) Blast program.

\subsection{Fermentation and Extraction}

Strain M30 (Penicillium sp.) was cultured in high-nutrient medium (30 g of instant ocean, $10 \mathrm{~g}$ of starch, $4 \mathrm{~g}$ of yeast, $2 \mathrm{~g}$ of peptone, $1 \mathrm{~g}$ of calcium carbonate, $40 \mathrm{mg}$ of iron sulfate, and $100 \mathrm{mg}$ of potassium bromate) for seven days at $25{ }^{\circ} \mathrm{C}$ while stirring at $200 \mathrm{rpm}$ in a bioreactor (Yuin, Seoul, Korea). The culture solution $(30 \mathrm{~L})$ was directly extracted with EtOAc $(15 \mathrm{~L} \times 3$ times $)$. The EtOAc extract solution was concentrated to dryness by a rotary evaporator (Eyela, Tokyo, Japan).

\subsection{Antimicrobial Assay}

The antimicrobial assay was carried out using E. coli (ATCC25922), P. aeruginosa (ATCC27853), S. enterica (ATCC12228), E. faecalis (ATCC13124), S. aureus (ATCC25923), B. cereus (ATCC13245), and C. albicans (ATCC1023). Stock solutions of samples were prepared in DMSO, and the antimicrobial assays were carried out in 96-well microtiter plates against the microbial strains $\left(5 \times 10^{5} \mathrm{CFU} / \mathrm{mL}\right)$ using a modification of the published method. After incubation for $24 \mathrm{~h}$ at $37^{\circ} \mathrm{C}$, the absorbance at $650 \mathrm{~nm}$ was measured using a microplate reader. Streptomycin and nystatin were used as reference compounds.

\section{6. $\alpha$-Glucosidase Inhibition Assay}

The inhibition of $\alpha$-glucosidase activity was determined using the modified, published assay [31]. Briefly, the reaction mixture consisting of $50 \mu \mathrm{L}$ of the sample at the indicated concentrations was incubated with $100 \mu \mathrm{L}$ of $0.1 \mathrm{M}$ potassium phosphate buffer ( $\mathrm{pH}$ 6.8) containing $\alpha$-glucosidase solution $(0.5 \mathrm{U} / \mathrm{mL})$ in 96 -well plates at $37^{\circ} \mathrm{C}$ for $10 \mathrm{~min}$. After pre-incubation, $50 \mu \mathrm{L}$ of 4 -Nitrophenyl $\beta$-D-glucopyranoside ( $\mathrm{pNPG}$ ) was added to each well to start the reaction. After incubating at $37^{\circ} \mathrm{C}$ 
for $10 \mathrm{~min}$, absorbance readings were recorded at $405 \mathrm{~nm}$ in a microplate reader (Biotek, Winooski, VT, Abbr of State, USA). The control sample was added to $50 \mu \mathrm{L}$ of buffer solution in place of the sample. Acarbose was used as a positive control of $\alpha$-glucosidase inhibitor. The $\alpha$-glucosidase inhibitory activity was calculated according to the equation below:

$$
\% \text { Inhibition }=1-\left(\mathrm{A}_{\text {sample }} / \mathrm{A}_{\text {control }}\right) \times 100
$$

where $\mathrm{A}_{\text {control }}$ is the absorbance of the control and $\mathrm{A}_{\text {sample }}$ is the absorbance of the tested samples.

\section{7. $\alpha$-Amylase Inhibition Assay}

The assay was carried out following the standard protocol with slight modifications [32]. Starch azure was suspended in $0.05 \mathrm{M}$ Tris- $\mathrm{HCl}$ buffer ( $\mathrm{pH}$ 6.9) containing $0.01 \mathrm{M} \mathrm{CaCl}_{2}$. The tubes containing the substrate solution were boiled for $5 \mathrm{~min}$ and then pre-incubated at $37^{\circ} \mathrm{C}$ for $5 \mathrm{~min}$. A total of $100 \mu \mathrm{L}$ of each sample and $100 \mu \mathrm{L}$ of substrate solution and $50 \mu \mathrm{L}$ of porcine pancreatic amylase in Tris- $\mathrm{HCl}$ buffer ( 2 units $/ \mathrm{mL}$ ) were incubated at $37^{\circ} \mathrm{C}$ for $10 \mathrm{~min}$. Then, $250 \mu \mathrm{L}$ of acetic acid $50 \%$ was added in each tube to stop the reaction. After, the reaction tubes were centrifuged at $3000 \mathrm{rpm}$ for $5 \mathrm{~min}$ at $4{ }^{\circ} \mathrm{C}$, the absorbance of the resulting supernatant was measured at $595 \mathrm{~nm}$ using a microplate reader (Biotek, USA).

The $\alpha$-amylase inhibitory activity was expressed as the percentage of inhibition and was calculated as follows:

$$
\% \text { Inhibition }=1-\left(\mathrm{A}_{\text {sample }} / \mathrm{A}_{\text {control }}\right) \times 100
$$

where $A_{\text {control }}$ is the absorbance of the control and $A_{\text {sample }}$ is the absorbance of the tested samples.

\subsection{Isolation of Compounds}

Sterilized Amberlite XAD-16 resin ( $2 \mathrm{~kg}$ ) was added to fermentation broth (50 L) to absorb the extracellular secondary metabolites. The culture medium and resin were shaken for $10 \mathrm{~h}$ and filtered using a cheesecloth to remove the resin. The resin, cell mass, and cheesecloth were extracted with methanol overnight, concentrated under vacuum, and partitioned between water and ethyl acetate. The organic layer was dried under vacuum to afford $26.4 \mathrm{~g}$ of extract. The organic layer $(26.4 \mathrm{~g})$ was separated by column chromatography (CC) eluted successively with $\mathrm{CH}_{2} \mathrm{Cl}_{2}-\mathrm{MeOH}$ to afford six fractions (E1-E6). Fraction E2 (5 g) was chromatographed over silica gel using $n$-hexane-acetone to get six subfractions (E2.1-E2.6). Fraction E3 (10 g) was subjected to silica gel CC and eluted with $\mathrm{CH}_{2} \mathrm{Cl}_{2}-\mathrm{MeOH}$ to get seven subfractions (E3.1-E3.7). Subfraction E3.1 (0.6 g) was purified by CC on Sephadex $\mathrm{LH}-20$ using $\mathrm{MeOH} / \mathrm{CH}_{2} \mathrm{Cl}_{2}(9: 1, \mathrm{v} / \mathrm{v})$ as an eluent to get sixx subfractions (E3.1.1-E3.1.6). Fraction E3.4 (170 mg) was separated by CC on Sephadex LH-20 using MeOH to get four subfractions (E3.4.1-E3.4.4). Fraction E4 was chromatographed on an RP-18 column eluting with MeOH: water to give seven subfractions, E4.1-E4.7. Subfraction E4.2 (1.99 g) was separated over Sephadex LH-20 eluted with $\mathrm{MeOH}$ to get seven subfractions (E4.2.1-E4.2.7). Sub-fraction E2.2 (100 mg) was chromatographed on silica gel eluted with $n$-hexane-acetone to yield $10(7.0 \mathrm{mg})$. Sub-fraction E3.1.2 (120 mg) was handled similar to E2.2 to yield $2.0 \mathrm{mg}$ of 4 and $3.0 \mathrm{mg}$ of 5 . By using CC (silica gel), sub-fraction E3.1.1, E4.2.5, and E4.2.7 was eluted individually with $n$-hexane-EtOAc, TLC $\mathrm{CH}_{2} \mathrm{Cl}_{2} / \mathrm{EtOAc}$ (4:6, $\mathrm{v} / \mathrm{v})$, and TLC $\left(\mathrm{CH}_{2} \mathrm{Cl}_{2} / \mathrm{MeOH}\right.$ : 9/1) gradient to yield 2, 8, and 9 (5.4, 4.1 and $2.5 \mathrm{mg}$, respectively). Subfraction E3.2 (0.1 g) was purified by CC on silica gel using $\mathrm{MeOH}$ as an eluent to yield 3 (7.4 mg). Subfraction E3.3 (90 mg) was purified by CC on Sephadex LH-20 (MeOH), followed by preparative TLC ( $n$-hexane/EtOAc/MeOH: 7/3/0.1) to furnish 6 (4 mg). Subfraction E3.4.3 (100 mg) was chromatographed on silica gel eluted with $\mathrm{CH}_{2} \mathrm{Cl}_{2}-\mathrm{MeOH}$ gradient, consequently gathered and checked by TLC $\left(\mathrm{CH}_{2} \mathrm{Cl}_{2} / \mathrm{MeOH}\right.$ : 9/1), where $\mathbf{1}(2.3 \mathrm{mg})$ and 7 (1.6 mg) were obtained.

Compound 1 (Sporogen AO-1): White amorphous powder; ${ }^{1} \mathrm{H}-\mathrm{NMR}\left(500 \mathrm{MHz}, \mathrm{CDCl}_{3}\right) \delta_{\mathrm{H}}(\mathrm{ppm}): 5.76(\mathrm{~d}$, $J=2,0 \mathrm{~Hz}, 1 \mathrm{H}, \mathrm{H}-9), 5.12$ (brs, 1H, H-12a), 5.10 (m, 1H, H-12b), 3.62 (td, J = 4,0, 10,5 Hz, H-3), 3.33 (s, 
1H, H-6), 2,51 (tdd, $J=2.0,5.0,14.5 \mathrm{~Hz}, \mathrm{H}-1 \mathrm{a}), 2.33(\mathrm{dt}, J=2.5,4.0,10.5 \mathrm{~Hz}, \mathrm{H}-1 \mathrm{~b}), 2.13-2,17(\mathrm{~m}, 1 \mathrm{H}$, H-2a), 1.87 (s, 3H, H-13), 1.80-1.83 (m, 1H, H-4), 1.42-1.49 (m, 1H, H-2b), 1.26 (d, J = 6.5 Hz, H-15), 1.23 (s, 3H, H-14); ${ }^{13} \mathrm{C}-\mathrm{NMR}\left(125 \mathrm{MHz}, \mathrm{CDCl}_{3}\right) \delta_{\mathrm{C}}$ (ppm): 192.8 (C-8), 162.9 (C-10), 139.1 (C-11), 121.2 (C-9), 114.5 (C-12), 71.0 (C-3), 68.3 (C-6), 64.5 (C-7), 44.4 (C-4), 41.0 (C-5), 35.2 (C-2), 31.0 (C-1), 19.8 (C-13), 18.8 (C-15), $11.3(\mathrm{C}-14)$.

Compound 2 (3-indolecarbadehyde): White amorphous powder; ${ }^{1} \mathrm{H}-\mathrm{NMR}\left(500 \mathrm{MHz}, \mathrm{CDCl}_{3}\right) \delta_{\mathrm{H}}(\mathrm{ppm})$ : $7.32(1 \mathrm{H}, \mathrm{m}, \mathrm{H}-5), 7.33(1 \mathrm{H}, \mathrm{m}, \mathrm{H}-6), 7.45(1 \mathrm{H}, \mathrm{m}, \mathrm{H}-7), 7.85(1 \mathrm{H}, \mathrm{d}, J=3.0 \mathrm{~Hz}, \mathrm{H}-2), 8.32(1 \mathrm{H}, \mathrm{m}, \mathrm{H}-4)$, $10.1(\mathrm{CHO}) ;{ }^{13} \mathrm{C}-\mathrm{NMR}\left(125 \mathrm{MHz}, \mathrm{CDCl}_{3}\right) \delta_{\mathrm{C}}(\mathrm{ppm}): 111.4$ (C-7), 120.1 (C-7a), $122.0(\mathrm{C}-4), 123.1$ (C-5), 124.0 (C-3), 124.5 (C-6), 135.1 (C-2), 136.9 (C-3a), 185.1 (CHO).

Compound 3 (2-((-5-methyl-1,4-dioxan-2-yl)methoxy)ethanol): Colorless oil; IR (KBr): 3454, 2866, 1456, 1373, 1350, 1296, 1251, $1105 \mathrm{~cm}^{-1}$; MS-ESI: $\mathrm{m} / z$ 199.09 [M + Na] ${ }^{+}$(cald. $\mathrm{C}_{8} \mathrm{H}_{16} \mathrm{NaO}_{4}: \mathrm{m} / \mathrm{z}$ 199.09); ${ }^{1} \mathrm{H}-\mathrm{NMR}\left(500 \mathrm{MHz}, \mathrm{CDCl}_{3}\right) \delta_{\mathrm{H}}(\mathrm{ppm}): 3.59(\mathrm{~m}, 1 \mathrm{H}, \mathrm{H}-2), 3.63(\mathrm{~m}, 2 \mathrm{H}, \mathrm{H}-3), 3.62(\mathrm{~m}, 1 \mathrm{H}, \mathrm{H}-5), 3.35(1 \mathrm{H}$, dd, $J=5.0,10.0 \mathrm{~Hz}, \mathrm{H}-6 \mathrm{a}), 3.47$ (1H, dd, $J=6.0,10.0 \mathrm{~Hz}, \mathrm{H}-6 \mathrm{~b}), 3.56$ (1H, m, H-1'a), 3.58 (1H, m, H-1'b), $3.59\left(2 \mathrm{H}, \mathrm{m}, \mathrm{H}-3^{\prime}\right), 3.59\left(2 \mathrm{H}, \mathrm{m}, \mathrm{H}-4^{\prime}\right), 1.10\left(3 \mathrm{H}, \mathrm{d}, J=6.5 \mathrm{~Hz}, \mathrm{CH}_{3}-5\right) ;{ }^{13} \mathrm{C}-\mathrm{NMR}\left(125 \mathrm{MHz}, \mathrm{CDCl}_{3}\right) \delta_{\mathrm{C}}$ (ppm): 71.2 (C-2), 69.2 (C-3), 75.5 (C-5), 75.7 (C-6), 71.5 (C-1'), $71.4\left(\mathrm{C}-3^{\prime}\right), 71.2\left(\mathrm{C}-4^{\prime}\right), 17.7\left(\mathrm{CH}_{3}-5\right)$.

Compound 4 (2-[(2R-hydroxypropanoyl)amino]benzamide): White amorphous powder; $[\alpha]_{\mathrm{D}}{ }^{28}+21.2(c 0.007$, acetone); ESI-MS: $\mathrm{m} / \mathrm{z} 231.07[\mathrm{M}+\mathrm{Na}]^{+} ;{ }^{1} \mathrm{H}-\mathrm{NMR}\left(500 \mathrm{MHz}, \mathrm{CD}_{3} \mathrm{OD}\right) \delta_{\mathrm{H}}(\mathrm{ppm}): 1.45(3 \mathrm{H}, \mathrm{d}, J=6.5$ $\left.\mathrm{Hz}, \mathrm{H}-3^{\prime}\right), 4.25\left(1 \mathrm{H}, \mathrm{q}, J=6.5 \mathrm{~Hz}, \mathrm{H}-2^{\prime}\right), 7.18(1 \mathrm{H}, \mathrm{t}, J=8.0 \mathrm{~Hz}, \mathrm{H}-5), 7.51(1 \mathrm{H}, \mathrm{dt}, J=1.0,8.0 \mathrm{~Hz}, \mathrm{H}-4)$, $7.53(1 \mathrm{H}, \mathrm{dd}, J=1.5,8.0 \mathrm{~Hz}, \mathrm{H}-6), 8.54(1 \mathrm{H}, \mathrm{dd}, J=1.0,8.0 \mathrm{~Hz}, \mathrm{H}-3) ;{ }^{13} \mathrm{C}-\mathrm{NMR}\left(125 \mathrm{MHz}, \mathrm{CD}_{3} \mathrm{OD}\right) \delta_{\mathrm{C}}$ (ppm): 21.1 (C-3'), 69.8 (C-2'), 122.2 (C-3), 122.8 (C-1), 124.5 (C-5), 129.4 (C-6), 133.3 (C-4), 139.6 (C-2), $173.3(\mathrm{C}-7), 176.6\left(\mathrm{C}-1^{\prime}\right)$.

Compound 5 (4-hydroxybenzaldehyde): White amorphous powder; ${ }^{1} \mathrm{H}-\mathrm{NMR}\left(500 \mathrm{MHz}, \mathrm{CDCl}_{3}\right) \delta_{\mathrm{H}}(\mathrm{ppm})$ : $6.95(2 \mathrm{H}, \mathrm{d}, J=8.5 \mathrm{~Hz}, \mathrm{H}$-aromatic), $7.80(2 \mathrm{H}, \mathrm{d}, J=8.5 \mathrm{~Hz}, \mathrm{H}-\mathrm{Phe}), 9.87(1 \mathrm{H}, \mathrm{s},-\mathrm{CHO})$.

Compound 6 (Chrysogine): Yellow powder, ${ }^{1} \mathrm{H}-\mathrm{NMR}\left(500 \mathrm{MHz}, \mathrm{CDCl}_{3}\right) \delta_{\mathrm{H}}(\mathrm{ppm}): 8.26(1 \mathrm{H}, \mathrm{d}, J=8.0 \mathrm{~Hz}$, $\mathrm{H}-3), 7.76(1 \mathrm{H}, \mathrm{t}, J=7.5 \mathrm{~Hz}, \mathrm{H}-5), 7.67(1 \mathrm{H}, \mathrm{d}, J=8.0 \mathrm{~Hz}, \mathrm{H}-6), 7.47(1 \mathrm{H}, \mathrm{t}, J=7.5 \mathrm{~Hz}, \mathrm{H}-4), 4.87(1 \mathrm{H}, \mathrm{q}$, $J=6.5 \mathrm{~Hz}, \mathrm{H}-9), 1.65(3 \mathrm{H}, \mathrm{d}, J=7.0 \mathrm{~Hz}, \mathrm{H}-10) .{ }^{13} \mathrm{C}-\mathrm{NMR}\left(125 \mathrm{MHz}, \mathrm{CDCl}_{3}\right) \delta_{\mathrm{C}}(\mathrm{ppm}): 162.8(\mathrm{C}-1)$, 157.9 (C-8), 148.6 (C-7), 134.9 (C-4), 127.2 (C-6), 126.9 (C-5), 126.5 (C-3), 121.0 (C-2), 67.5 (C-9), 22.5 (C-10).

Compound 7 (3-Acetyl-4-hydroxycinnoline): Yellow powder; IR $v_{\max } 3412$ and $1669 \mathrm{~cm}^{-1}$; HR-ESI-MS m/z $189.0657[\mathrm{M}+\mathrm{H}]^{+}$(calculated for $\mathrm{C}_{10} \mathrm{H}_{9} \mathrm{~N}_{2} \mathrm{O}_{2} \mathrm{~m} / \mathrm{z}$ 189.0664); ${ }^{1} \mathrm{H}-\mathrm{NMR}\left(500 \mathrm{MHz}, \mathrm{CDCl}_{3}\right) \delta_{\mathrm{H}}(\mathrm{ppm})$ : $9.95(1 \mathrm{H}, \mathrm{brs}, \mathrm{OH}), 8.36(1 \mathrm{H}, \mathrm{d}, J=8.0 \mathrm{~Hz}, \mathrm{H}-5), 7.89(1 \mathrm{H}, \mathrm{d}, J=8.0 \mathrm{~Hz}, \mathrm{H}-8), 7.85(1 \mathrm{H}, \mathrm{t}, J=8.0 \mathrm{~Hz}, \mathrm{H}-7)$, $7.63(1 \mathrm{H}, \mathrm{t}, J=8.0 \mathrm{~Hz}, \mathrm{H}-6), 2.77$ (3H, s, H-10); ${ }^{13} \mathrm{C}-\mathrm{NMR}\left(125 \mathrm{MHz}, \mathrm{CDCl}_{3}\right) \delta_{\mathrm{C}}(\mathrm{ppm}): 24.0(\mathrm{C}-10), 123.5$ (C-4a), 126.9 (C-5), 129.2 (C-8), 129.4 (C-6), 134.9 (C-7), 145.3 (C-3), 147.7 (C-8a), 160.6 (C-4), 194.1 (C-9).

Compound 8 (1H-Indole-3-acetic acid): White amophous powder; ${ }^{1} \mathrm{H}-\mathrm{NMR}\left(500 \mathrm{MHz}, \mathrm{CD}_{3} \mathrm{OD}\right) \delta_{\mathrm{H}}(\mathrm{ppm})$ : $3.62\left(1 \mathrm{H}, \mathrm{s}, \mathrm{CH}_{2}\right), 6.98(1 \mathrm{H}, \mathrm{dt}, J=1.0,8.0 \mathrm{~Hz}, \mathrm{H}-5), 7.06(1 \mathrm{H}, \mathrm{dt}, J=1.0,8.0 \mathrm{~Hz}, \mathrm{H}-6), 7.15(1 \mathrm{H}, \mathrm{s}, \mathrm{H}-2)$, $7.31(1 \mathrm{H}, \mathrm{dd}, J=0.5,8.0 \mathrm{~Hz}, \mathrm{H}-7), 7.62(1 \mathrm{H}, \mathrm{d}, J=0.5,8.0 \mathrm{~Hz}, \mathrm{H}-4)$.

Compound 9 (Cyclo (Tyr-Trp)): White amophous powder; ${ }^{1} \mathrm{H}-\mathrm{NMR}(500 \mathrm{MHz}, \mathrm{MeOD}) \delta_{\mathrm{H}}$ (ppm): 1.48 $\left[1 \mathrm{H}, \mathrm{dd}, J=8.5,13.5 \mathrm{~Hz}, \mathrm{CH}_{2 \mathrm{a}}(\mathrm{Tyr})\right], 2.57\left[1 \mathrm{H}, \mathrm{dd}, J=4.0,14.0 \mathrm{~Hz}, \mathrm{CH}_{2 \mathrm{~b}}(\mathrm{Tyr})\right], 2.76[1 \mathrm{H}, \mathrm{dd}, J=6.0$, $\left.14.5 \mathrm{~Hz}, \mathrm{CH}_{2 \mathrm{a}}(\operatorname{Trp})\right], 3.05\left[1 \mathrm{H}, \mathrm{dd}, J=4.0,14.5 \mathrm{~Hz}, \mathrm{CH}_{2 \mathrm{~b}}(\operatorname{Trp})\right], 3.87[1 \mathrm{H}, \mathrm{dd}, J=3.5,8.5 \mathrm{~Hz}, \mathrm{H}-3), 4.16$ $(1 \mathrm{H}, \mathrm{t}, J=5.0 \mathrm{~Hz}, \mathrm{H}-6), 6.46(2 \mathrm{H}, \mathrm{d}, J=7.5 \mathrm{~Hz}, \mathrm{H}-\mathrm{Tyr}), 6.63(2 \mathrm{H}, \mathrm{d}, J=7.5 \mathrm{~Hz}, \mathrm{H}-\mathrm{Tyr}), 7.03-7.60(5 \mathrm{H}$, H-Trp); ${ }^{13} \mathrm{C}-\mathrm{NMR}(125 \mathrm{MHz}, \mathrm{MeOD}) \delta_{\mathrm{C}}(\mathrm{ppm}): 31.2\left(\mathrm{CH}_{2}\right), 40.6\left(\mathrm{CH}_{2}\right), 57.1(\mathrm{CH}), 57.9(\mathrm{CH}), 109.6-157.5$ (C-Tyr và C-Trp), $169.3(\mathrm{C}=\mathrm{O}), 169.7(\mathrm{C}=\mathrm{O})$.

Compound 10 (2',3'-dihydrosorbicillin): Yellow powder; ${ }^{1} \mathrm{H}-\mathrm{NMR}\left(500 \mathrm{MHz}, \mathrm{CD}_{3} \mathrm{OD}\right) \delta_{\mathrm{H}}(\mathrm{ppm}): 7.59(\mathrm{~s}$, 1H, H-6), 5.53-5.54 (m, 2H, H-4' and H-5'), 3.06 (t, $\left.J=7.5 \mathrm{~Hz}, \mathrm{H}-2^{\prime}\right), 2.35-2.43\left(\mathrm{~m}, 2 \mathrm{H}, \mathrm{H}-3^{\prime}\right), 2.39$ (s, 3H, H-7), 2.27 (s, 3H, H-8), 1.65 (m, 3H, H-6'); ${ }^{13} \mathrm{C}-\mathrm{NMR}\left(125 \mathrm{MHz}, \mathrm{CD}_{3} \mathrm{OD}\right) \delta_{\mathrm{C}}(\mathrm{ppm}): 207.4\left(\mathrm{C}-1^{\prime}\right), 161.5$ 
(C-2), 156.7 (C-4), 130.9 (C-6), 130.1 (C-4'), 127.0 (C-5'), 124.9 (C-5), 122.8 (C-3), 117.3 (C-1), 39.2 (C-2'), $28.6\left(\mathrm{C}-3^{\prime}\right), 18.0\left(\mathrm{C}-6^{\prime}\right), 17.2(\mathrm{C}-7), 10.3(\mathrm{C}-8)$.

\subsection{Statistical Analysis}

Data were expressed as the mean \pm standard deviations (SD). Statistical significance was assessed by the two-tailed unpaired Student's $t$-test, and $\mathrm{P}$ values less than 0.05 were considered statistically significant.

\section{Conclusions}

In recent years, ordinary natural-derived Penicillium sp. is among the most attentive fungi in the science of natural products. In our experiments, we identified the Penicillium strain M30 from sediment collecting at a depth of $14 \mathrm{~m}$ at the Co To island, the North of Vietnam's sea. After fermentation, we found that the extract of fermentation broth of this sp. showed significant antimicrobial and $\alpha$-glucosidase $/ \alpha$-amylase inhibitory activities. Extraction and isolation results yielded a new natural product, 3-acetyl-4-hydroxycinnoline (7), and nine known metabolites as sporogen AO-1 (1), 3-indolecarbadehyde (2), 2-[(5-methyl-1,4-dioxan-2-yl)methoxy]ethanol (3), 2-[(2R-hydroxypropanoyl)amino]benzamide (4), 4-hydroxybenzandehyde (5), chrysogine (6), acid 1H-Indole-3-acetic (8), cyclo (Tyr-Trp) (9), and 2',3'-dihydrosorbicillin (10). Among the isolates, 2-[(5-methyl-1,4-dioxan-2-yl) methoxy]ethanol (3) showed a strong inhibitory effect against $E$. faecalis with a MIC value of $32 \mu \mathrm{g} / \mathrm{mL}$. Both of 2-[(2R-hydroxy propanoyl) amino] benzamide (4) and 4-hydroxybenzandehyde (5) selectively killed E. coli with MIC values of 16 and $8 \mu \mathrm{g} / \mathrm{mL}$, respectively. $2^{\prime}, 3^{\prime}$-Dihydrosorbicillin (10) potentially inhibited activity at a concentration of $2.0 \mathrm{mM}(66.31 \%$ $\alpha$-glucosidase). This study highlights the value of Penicillium sp. derivation from sediment as a source of antimicrobial, antifungal, and anti- $\alpha$-glucosidase compounds with the potential to combat afflicting pathogens and diabetic diseases.

Author Contributions: Investigation, data curation-H.M.T.L., Q.T.D., M.H.T.D., T.H.T.V., Q.T.V. and M.A.N.; Supervision-V.M.C., and V.C.P.; Writing—original draft-N.T.T.D., H.D.N. and M.H.T.

Funding: This research was funded by a VAST project coded VAST04.07/17-18.

Conflicts of Interest: The authors declare no conflict of interest.

\section{References}

1. Roca, I.; Akova, M.; Baquero, F.; Carlet, J.; Cavaleri, M.; Coenen, S.; Cohen, J.; Findlay, D.; Gyssens, I.; Heuer, O.E.; et al. The global threat of antimicrobial resistance: Science for intervention. New Microbes New Infect. 2015, 6, 22-29. [CrossRef] [PubMed]

2. Parrino, B.; Schillaci, D.; Carnevale, I.; Giovannetti, E.; Diana, P.; Cirrincione, G.; Cascioferro, S. Synthetic small molecules as anti-biofilm agents in the struggle against antibiotic resistance. Eur. J. Med. Chem. 2019, 161, 154-178. [CrossRef] [PubMed]

3. Baym, M.; Stone, L.K.; Kishony, R. Multidrug evolutionary strategies to reverse antibiotic resistance. Science 2016, 351, 6268. [CrossRef] [PubMed]

4. Parrino, B.; Attanzio, A.; Spano, V.; Cascioferro, S.; Montalbano, A.; Barraja, P.; Tesoriere, L.; Diana, P.; Cirrincione, G.; Carbone, A. Synthesis, antitumor activity and CDK1 inhibiton of new thiazole nortopsentin analogues. Eur. J. Med. Chem. 2017, 138, 371-383. [CrossRef] [PubMed]

5. Habbu, P.; Warad, V.; Shastri, R.; Madagundi, S.; Kulkarni, V.H. Antimicrobial metabolites from marine microorganisms. Chin. J. Nat. Med. 2016, 14, 101-116. [CrossRef]

6. Schwartsmann, G.; Brondani da Rocha, A.; Berlinck, R.G.; Jimeno, J. Marine organisms as a source of new anticancer agents. Lancet Oncol. 2001, 2, 221-225. [CrossRef]

7. Haefner, B. Drugs from the deep: Marine natural products as drug candidates. Drug Discov. Today. 2003, 8, 536-544. [CrossRef]

8. Rawat, D.S.; Joshi, M.C.P.; Atheaya, H. Marine peptides and related compounds in clinical trial. Anticancer Agents Med. Chem. 2006, 6, 33-40. [CrossRef] 
9. Donadio, S.; Monciardini, P.; Alduina, R.; Mazza, P.; Chiocchini, C.; Cavaletti, L.; Sosio, M.; Puglia, A.M. Microbial technologies for the discovery of novel bioactive metabolites. J. Biotechnol. 2002, 99, 187-198. [CrossRef]

10. Keller, M.; Zengler, K. Tapping into microbial diversity. Nat. Rev. Microbiol. 2004, 2, 141-150. [CrossRef]

11. Sonjak, S.; Frisvad, J.C.; Gunde-Cimerman, N. Penicillium mycobiota in arctic subglacial ice. Microb. Ecol. 2006, 52, 207-216. [CrossRef] [PubMed]

12. Stierle, D.B.; Stierle, A.A.; Patacini, B. The berkeleyacetals, three meroterpenes from a deep water acid mine waste Penicillium. J. Nat. Prod. 2007, 70, 1820-1823. [CrossRef] [PubMed]

13. Du, L.; Li, D.; Zhu, T.; Cai, S.; Wang, F.; Xiao, X.; Gu, Q. New alkaloids and diterpenes from a deep ocean sediment derived fungus Penicillium sp. Tetrahedron 2009, 65, 1033-1039. [CrossRef]

14. Rančić, A.; Soković, M.; Karioti, A.; Vukojević, J.; Skaltsa, H. Isolation and structural elucidation of two secondary metabolites from the filamentous fungus Penicillium ochrochloron with antimicrobial activity. Environ. Toxicol. Pharmacol. 2006, 22, 80-84. [CrossRef] [PubMed]

15. Lucas, E.M.F.; Castro, M.C.M.; Takahashi, J.A. Antimicrobial properties of sclerotiorin, isoc Hromophilone VI and pencolide, metabolites from a Brazilian cerrado isolate of Penicillium sclerotiorum van Beyma. Braz. J. Microbiol. 2007, 38, 785-789. [CrossRef]

16. Nicoletti, R.; Lopez-Gresa, M.P.; Manzo, E.; Carella, A.; Ciavatta, M.L. Production and fungitoxic activity of Sch 642305, a secondary metabolite of Penicillium canescens. Mycopathologia 2007, 163, 295-301. [CrossRef] [PubMed]

17. Kwon, O.E.; Rho, M.C.; Song, H.Y.; Lee, S.W.; Chung, M.Y.; Lee, J.H.; Kim, Y.H.; Lee, H.S.; Kim, Y.K. Phenylpyropene A and B, new inhibitors of acyl-CoA: Cholesterol acyltransferase produced by Penicillium griseofulvum F1959. J. Antibiot. 2002, 55, 1004-1008. [CrossRef]

18. Frisvad, J.; Samson, R. Polyphasic taxonomy of Penicillium subgenus Penicillium. A guide to identif cation of food and airborne terverticillate Penicillia and their mycotoxins. Stud. Mycol. 2004, 49, 1-174.

19. Lin, Z.J.; Lu, Z.Y.; Zhu, T.J.; Fang, Y.C.; Gu, Q.Q.; Zhu, W.M. Penicillenols from Penicillium sp. GQ-7, an endophytic fungus associated with Aegiceras corniculatum. Chem. Pharm. Bull. 2008, 56, 217-221. [CrossRef]

20. Lin, Z.; Zhu, T.; Fang, Y.; Gu, Q.; Zhu, W. Polyketides from Penicillium sp. JP-1, an endophytic fungus associated with the mangrove plant Aegiceras corniculatum. Phytochemistry 2008, 69, 1273-1278. [CrossRef]

21. Ge, H.M.; Shen, Y.; Zhu, C.H.; Tan, S.H.; Ding, H.; Song, Y.C.; Tan, R.X. Penicidones A-C, three cytotoxic alkaloidal metabolites of an endophytic Penicillium sp. Phytochemistry 2008, 69, 571-576. [CrossRef]

22. Nakajima, E.; Nakano, H.; Yamada, K.; Shigemori, H.; Hasegawa, K. Isolation and identification of lateral bud growth inhibitor, indole-3-aldehyde, involved in apical dominance of pea seedlings. Phytochemistry 2002, 61, 863-865. [CrossRef]

23. Thi, Q.V.; Tran, V.; Mai, H.; Le, C.V.; Hong, T.M.; Murphy, B.T.; Chau, V.M.; Pham, V.C. Secondary metabolites from an Actinomycete from Vietnam's East Sea. Nat. Prod. Commun. 2016, 11, 401-404. [CrossRef] [PubMed]

24. Bergman, J.; Brynolf, A. Synthesis of chrysogine, a metabolite of Penicillium chrysogenum and some related 2-substituted 4-(3H)-quinazolinones. Tetrahedron 1990, 46, 1295-1310. [CrossRef]

25. Chimatadar, S.; Basavaraj, T.; Nandibewoor, S. A study of the kinetics and mechanism of oxidation of L-tryptophan by diperiodatonickelate(IV) in aqueous alkaline medium. Russ. J. Phys. Chem. A 2007, 81, 1046-1053. [CrossRef]

26. Ivanova, V.; Laatsch, H.; Kolarova, M.; Aleksieva, K. Structure elucidation of a new natural diketopiperazine from a Microbispora aerata strain isolated from Livingston Island, Antarctica. Nat. Prod. Res. 2013, 27, 164-170. [CrossRef] [PubMed]

27. Youssef, M.S.K.; El-Dean, A.M.K.; Abbady, M.S.; Hassan, K.M. Synthesis and some reactions of cinnoline derivatives. Collect. Czechoslov. Chem. Commun. 1991, 56, 1768-1775. [CrossRef]

28. Friedman, M.; Henika, P.R.; Mandrell, R.E. Antibacterial activities of phenolic benzaldehydes and benzoic acids against Campylobacter jejuni, Escherichia coli, Listeria monocytogenes, and Salmonella enterica. J. Food Prot. 2003, 66, 1811-1821. [CrossRef]

29. Alamri, A.; El-Newehy, M.H.; Al-Deyab, S.S. Biocidal polymers: Synthesis and antimicrobial properties of benzaldehyde derivatives immobilized onto amine-terminated polyacrylonitrile. Chem. Cent. J. 2012, 6, 111. [CrossRef] 
30. Mabkhot, Y.N.; Al-Majid, A.M.; Barakat, A.; Al-Showiman, S.S.; Al-Har, M.S.; Radi, S.; Naseer, M.M.; Hadda, T.B. Synthesis and biological evaluation of 2-aminobenzamide derivatives as antimicrobial agents: Opening/closing pharmacophore site. Int. J. Mol. Sci. 2014, 15, 5115-5127. [CrossRef]

31. Ranilla, L.G.; Kwon, Y.I.; Apostolidis, E.; Shetty, K. Phenolic compounds, antioxidant activity and in vitro inhibitory potential against key enzymes relevant for hyperglycemia and hypertension of commonly used medicinal plants, herbs and spices in Latin America. Bioresour. Technol. 2010, 101, 4676-4689. [CrossRef] [PubMed]

32. Hansawasdi, C.; Kawabata, J.; Kasai, T. Alpha-amylase inhibitors from roselle (Hibiscus sabdariffa Linn.) tea. Biosci. Biotechnol. Biochem. 2000, 64, 1041-1043. [CrossRef] [PubMed]

Sample Availability: Samples of the compounds 1-10 are available from the authors.

(C) 2019 by the authors. Licensee MDPI, Basel, Switzerland. This article is an open access article distributed under the terms and conditions of the Creative Commons Attribution (CC BY) license (http://creativecommons.org/licenses/by/4.0/). 